\title{
Prosthetic treatment of temporomandibular disorders and lateral functional mandibular dislocation
}

\author{
Leczenie protetyczne pacjenta z zaburzeniami czynnościowymi układu \\ ruchowego narządu żucia i bocznym czynnościowym przesunięciem żuchwy
}

\section{Mariusz Adam Kochanowski, Kamila Rogowska, Beata Dorota Dejak}

Zakład Protetyki Stomatologicznej, Uniwersytet Medyczny w Lodzi Department of Prosthodontics, Medical University in Lodz Head: prof. dr hab. n. med. Beata Dejak

KEY WORDS:

prosthodontics, CBCT, NTI, Sliding Guide, deprogramming

\section{Summary}

The aim of the study was to present prosthetic treatment of the patient suffering from temporomandibular disorders and lateral functional mandibular dislocation.

After initial diagnostics, physical examination of the patient and the interview, panoramic $x$-ray and a CBCT scan of temporomandibular joints were taken.

The Cone Beam Computed Tomography $(C B C T)$ scan enables diagnosing the location of mandibular heads in temporomandibular joint (TMJ). The therapy was initiated with the patient being treated with physiotherapy.

In order to perform the deprogramming procedure a NTI splint was used for 1.5 months, three times a day for 1.5 hours in a natural position. In preparation for the prosthetic treatment, the sources of the infection were eliminated. Implants were placed. Deprogramming with the use of Sliding Guide was performed. Then the models were fixed in an articulator in the centric relation. Wax-up was performed. On its basest a mockup was prepared. Temporary appliances were used for three months. After this period, the final prosthetic appliances such as veneers, overdenture, bridge and implant crowns were made.
HASŁA INDEKSOWE:

protetyka, CBCT, NTI, Sliding Guide, deprogramacja

\section{Streszczenie}

Celem pracy byto przedstawienie leczenia protetycznego pacjenta z zaburzeniami czynnościowymi układu ruchowego narzadu żucia i bocznym czynnościowym przesunięciem żuchwy.

Pacjenta poddano wstepnej diagnostyce, wykonano badania podmiotowe $i$ przedmiotowe, zdjęcia pantomograficzne i CBCT stawów skroniowo-żuchwowych.

Tomografia stożkowa o zmiennym polu obrazowania (CBCT) umożliwita ustalenie położenia głów żuchwy $w$ stawie skroniowo-żuchwowym (Temporomandibular Joint - TMJ). Pacjenta poddano fizjoterapii.

Zastosowano deprogramacje $z$ wykorzystaniem szyny NTI, która stosowana była przez 1,5 miesiaca 3 razy dziennie po 1,5 godziny w pozycji naturalnej. Wykonano sanacje jamy ustnej. Wszczepiono implanty. Przeprowadzono deprogramacje z uzyciem deprogramatora Sliding Guide. Nastepnie modele zamontowano $w$ artykulatorze w pozycji okluzji centralnej $i$ wykonano wax-up. Na jego podstawie wykonano mock-up. Tymczasowe uzupetnienia byty użytkowane przez pacjenta przez 6 miesięcy. Po tym czasie wykonano i zacementowano prace docelowe: licówki, naktady, mosty i korony na implantach. 
By deprogramming and establishing the centric relation, stable occlusion can be achieved. The nine-year observation period has proven that the prosthetic appliances have not been damaged.

\section{Introduction}

Temporomandibular disorders (TMD) are diagnosed in the ever increasing number of patients. It is a disease characterized by functional balance disorders of the stomatognathic system or even damage to it. Those disorders are accompanied by an increase of neuro-muscular tension. ${ }^{1}$ They appear as a result of stress, presence of parafunctions and occlusion disorders. The relevant risk factors of increased muscle tension is lack of orthopedic stability that is a result of incompatibility of centric occlusion and habitual occlusion, the presence of occlusal trauma, iatrogenic errors and malocclusion. ${ }^{1}$ The main symptoms of TMD include 'smyalgia and arthralgia's, mandibular movement abnormalities and acoustic phenomena in the temporomandibular joint TMJ. ${ }^{1}$

Lateral functional mandibular shift is a transverse maxillofacial defect. It is characterized by an intraoral complete crossbite with a significant shift in the interincisal midline, and a contralateral scissor bite. ${ }^{2}$ The skeletal midline shift is visible in relation to body and teeth midline. ${ }^{2}$ The disorder is visible in the patient's facial features in the form of collapsed upper lip, a deepening of the nasolabial fold, bulging of the lower lip and a shift of the chin towards the defect. The interocclusal pathway is deflected towards the defect, and the lateral movements of the mandible are restricted. A positive functional test result - the improvement of patient's facial features and occlusal situation - can differentiate this pathology from
Dzięki deprogramacji i ustaleniu okluzji centralnej można uzyskać stabilne zwarcie. Dziewięcioletnie obserwacje dowodza, że zastosowane docelowe uzupetnienia protetyczne nie ulegty uszkodzeniu.

\section{Wstęp}

Zaburzenia czynnościowe układu ruchowego narządu żucia ZCURNŻ stanowią problem u coraz większej liczby pacjentów. Stanowią zespół chorobowy charakteryzujący się zaburzeniami równowagi czynnościowej lub uszkodzeniem układu stomatognatycznego $\mathrm{z}$ towarzyszącym mu wzrostem napięcia nerwowo-mięśniowego. ${ }^{1}$ Wynikają między innymi ze stresu, obecności parafunkcji i zaburzeń zwarcia. Istotnymi czynnikami ryzyka powstania wzmożonego napięcia mięśni jest brak stabilności ortopedycznej wynikający z niezgodności zwarcia centralnego ze zwarciem nawykowym, obecności urazów zgryzowych, błędów jatrogennych oraz wad zgryzu. ${ }^{1}$ Do głównych objawów ZCURNŻ zalicza się bóle mięśni i stawów, zaburzenia ruchu żuchwy oraz zjawiska akustyczne w stawie. ${ }^{1}$

Czynnościowe boczne przesunięcie żuchwy to wada poprzeczna szczękowo-zgryzowa. Charakteryzuje się śródustnym występowaniem zgryzu krzyżowego całkowitego ze znacznym przesunięciem linii pośrodkowej zębów siecznych, przy jednoczesnym występowaniu zgryzu przewieszonego po stronie przeciwnej. Linia pośrodkowa szkieletowa jest przesunięta $\mathrm{w}$ stosunku do linii pośrodkowej ciała i łuku zębowego. ${ }^{2} \mathrm{~W}$ rysach twarzy zaburzenie to uwidacznia się $\mathrm{w}$ postaci zapadnięcia wargi górnej, pogłębienia fałdu nosowo-wargowego, uwypuklenia wargi dolnej i przesunięcia bródki w stronę wady. Droga interokluzyjna wykazuje odchylenie w stronę wady, boczne ruchy żuchwy są ograniczone. Celem 
the morphological abnormality. The skeletal midline is offset from the midline of the body and the dental arch. Lateral displacement of the chin (pogonion, $\mathrm{Pg}$ ) is observed. ${ }^{2}$

The incidence of lateral functional mandibular shift in primary dentition is $8.4 \%$ and in mixed dentition $7.2 \%$. Self-correction of this abnormality occurs in a maximum of $9 \%$ of cases, therefore therapy is the recommended approach.. ${ }^{3}$ In the case of primary dentition, lateral functional mandibular shift is treated by correcting premature occlusal contacts and performing muscle exercises. These exercises consist in re-educating the patient in the actions of swallowing and holding the lower jaw while closing the mouth in a way that prevents it from deviating. To achieve this goal, the Andresen activator with a lower labial bow, an active upper plate, and an acrylic pad for the lower posterior teeth on the side opposite to the crossbite are used. ${ }^{3}$ In the case of mixed dentition in adolescent patients, devices that enable the expansion of the maxilla, e.g. the Schwarz upper plate, are used. They enable rapid correction of an orthodontic defect. ${ }^{4}$

In the case of adults, orthodontic treatment of lateral functional mandibular shift involves expanding the maxilla by means of devices that open the mid-palatal suture, such as a Hyrax screw device. ${ }^{4}$ There is a group o patients that do not agree to undergo surgical procedure. An alternative to orthodontic treatment in adults with this defect involves camouflaging the defect with prosthetic restorations. This involves placing the patient's mandible in the centric relation przypis 5 and rebuilding the occlusal surface of the teeth, keeping the mandible in this position. With this aim in mind, the dentist performs a muscle deprogramming procedure. The dentist determines the vertical dimension of occlusion and the position of the mandible in the centric relation and records this position ${ }^{6}$. Models of the patient's dentition are mounted in the articulator in this position. ${ }^{7}$ Przypis 6 On the basis of the diagnostyki różnicowej z morfologiczną wadą wykonuje się test czynnościowy. Polega on na obserwacji rysów twarzy w momencie przesunięcia żuchwy tak, aby linia pośrodkowa była zgodna z linią pośrodkową ciała. Dodatni test czynnościowy, w którym dojdzie do poprawy rysów twarzy i warunków zgryzowych u pacjenta, świadczy o wadzie czynnościowej. ${ }^{2}$

Częstość występowania czynnościowego bocznego przesunięcia żuchwy w uzębieniu mlecznym wynosi 8,4\% i a w mieszanym 7,2\%. Do samokorekty tej nieprawidłowości dochodzi maksymalnie w 9\% przypadków, dlatego zalecana jest terapia tych pacjentów. ${ }^{3} \mathrm{~W}$ uzębieniu mlecznym leczenie czynnościowego bocznego przesunięcia żuchwy polega na usunięciu przedwczesnych kontaktów zębowych i ćwiczeniach mięśniowych. Ćwiczenia polegają na reedukacji połykania oraz przytrzymywaniu żuchwy podczas zamykania jamy ustnej w sposób uniemożliwiający jej zbaczanie. Stosuje się aktywator Andresena z dolnym łukiem wargowym, płytę aktywną górną, pelotę akrylową na zęby boczne dolne po stronie przeciwnej do zgryzu krzyżowego. ${ }^{2} \mathrm{~W}$ uzębieniu mieszanym pacjentów młodocianych stosuje się aparaty, które pozwalają na rozbudowę szczęki np. płytę górną Schwarza. Pozwalają one na szybką korektę wady ortodontycznej. ${ }^{3}$

U ludzi dorosłych, ortodontyczne leczenie czynnościowego bocznego przesunięcia żuchwy polega na ekspansji szczęki z wykorzystaniem aparatów rozrywających szew podniebienny np. aparatu ze śrubą Hyrax. ${ }^{4}$ Nie wszyscy pacjenci decydują się na rozległy zabieg chirurgiczny. Alternatywą dla leczenia ortodontycznego tej wady u dorosłych jest kamuflaż wady wykonany z wykorzystaniem uzupełnień protetycznych. Leczenie to polega na ustaleniu pozycji najbardziej korzystnej dla stawu skroniowo-żuchwowego (relacja centralna). ${ }^{5} \mathrm{~W}$ tym celu wykonuje się deprogramację pacjenta. W tej pozycji modele są montowane w artykulatorze. ${ }^{6}$ Technik wykonuje 
master cast, the technician produces a diagnostic wax-up until balanced occlusion is achieved. The wax-up serves as the basis for making a silicone index that transfers the corrected teeth shape to the mouth (in the form of a mock-up). That is how interim restorations are created. i tworzone są prace tymczasowe. The patient wears a temporary restoration with the proper construction bite for a period of 3-12 months. After this period, the treatment is consolidated with the placement of fixed restorations.

\section{Case report}

The aim of this case report is to describe the prosthetic treatment provided for a patient with TMD and lateral functional mandibular dislocation.

\section{Diagnostics}

A 67-year-old male patient presented at the Clinic in 2012 for the prosthetic reconstruction of the teeth and replacement of old prosthetic restorations (bridges) in the posterior regions of the dentition. The patient's medical history revealed recurrent headaches in the left temporal area, a sensation of excessive tension in the head and neck muscles, and morning muscle fatigue.

An extraoral examination revealed a lack of facial symmetry and displacement of the chin $2 \mathrm{~mm}$ to the left in relation to the midline of the body (Fig. 1a). On the left side, increased tension was observed in the masseter, temporal, medial pterygoid and digastric muscles. On the right side, tension affected the temporal and lateral pterygoid muscles.

In anamnestic part of the Helkimo test patient reported mild subjective symptoms such as audible clicking in TMJ area, pain and fatigue of the masticatory muscles and in the neck area. Clinically, slight irregularities in the mandible movements were noted, with a $5 \mathrm{~mm}$ deviation to the left. The patient woskowanie zębów na modelach roboczych (wax-up), aby uzyskać prawidłową płaszczyznę zwarcia i okluzję. Na podstawie wax-up wykonywany jest indeks silikonowy, za pomocą którego poprawiony kształt zębów przenoszony jest do jamy ustnej (mock-up) i wykonywane są prace tymczasowe. Uzupełnienia tymczasowe w nowym układzie zwarcia konstrukcyjnego pacjent użytkuje przez okres 3 miesięcy do 1 roku. Po tym czasie wykonywane są uzupełnienia długoczasowe.

\section{Opis przypadku}

Celem pracy jest przedstawienie protetycznego leczenia pacjenta z zaburzeniami czynnościowymi układu ruchowego narządu żucia i bocznym czynnościowym przesunięciem żuchwy.

\section{Diagnostyka}

W roku 2012 do kliniki zgłosił się pacjent, lat 67 w celu odbudowy protetycznej braków zębowych oraz wymiany uzupełnień protetycznych (mostów) w odcinkach bocznych uzębienia.

W wywiadzie stwierdzono nawracające bóle głowy w okolicy lewej skroni, uczucie nadmiernego napięcia w obrębie mięśni głowy i szyi, poranne zmęczenie mięśniowe. $W$ badaniu zewnątrzustnym zaobserwowano brak symetrii twarzy, przemieszczenie bródki w stronę lewą w stosunku do linii pośrodkowej ciała (ryc.1a). Po stronie lewej, występowało wzmożone napięcie mięśni: żwacza, skroniowego, skrzydłowego przyśrodkowego oraz dwubrzuścowego. Po stronie prawej: napięcie mięśnia skroniowego oraz skrzydłowego bocznego. W części anamnestycznej testu Helkimo pacjent podawał niewielkie objawy subiektywne, takie jak: słyszalne trzaski w okolicy stawów skroniowo-żuchwowych, ból i uczucie zmęczenia mięśni żucia oraz okolicy szyi. W części klinicznej stwierdzono nieznacznie zaburzoną amplitudę ruchów żuchwy, ze zboczeniem 

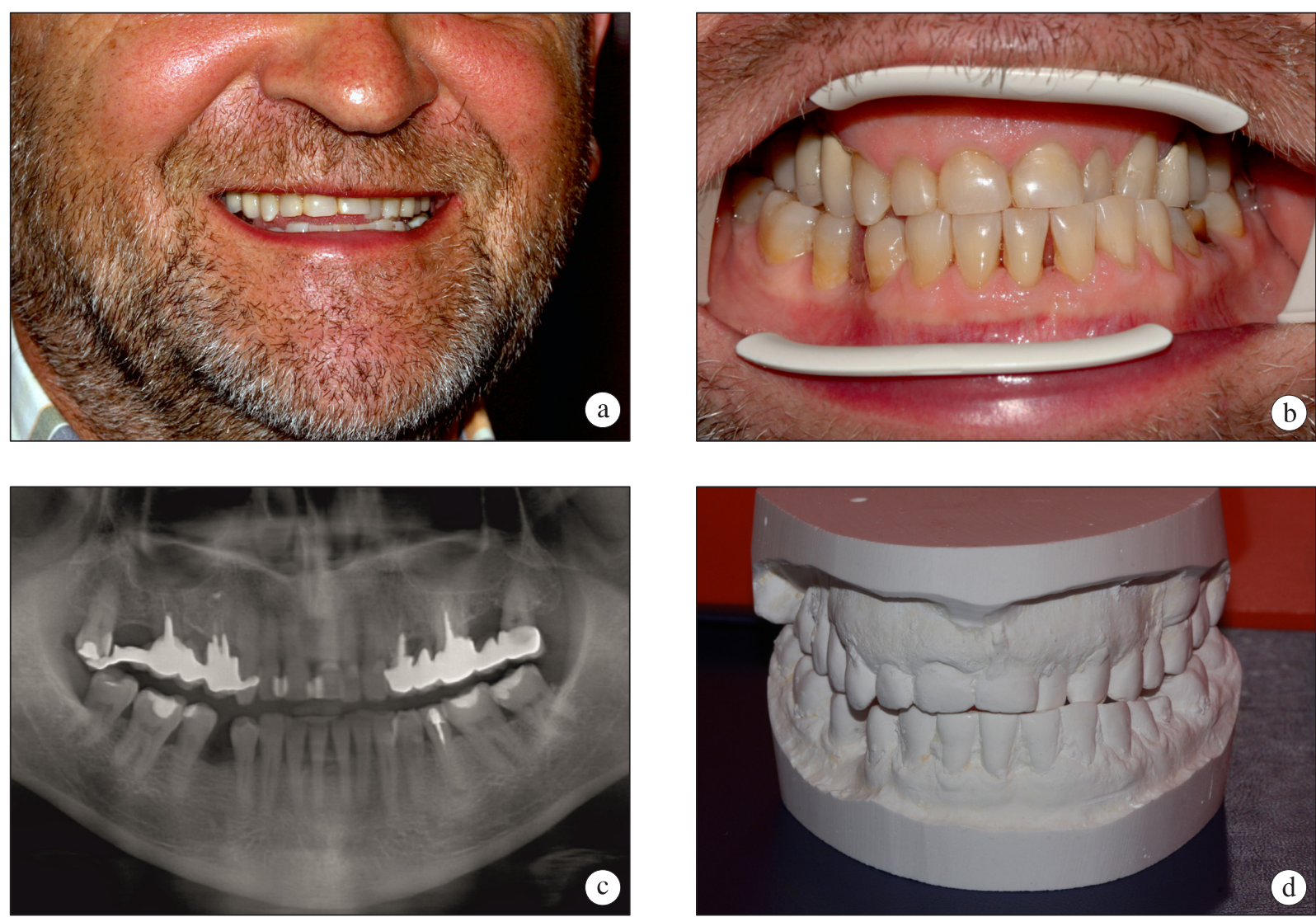

Fig. 1a. Before treatment; a - extraoral view, $b$ - intraoral view, $c$-RTG OPG, $d$-study cast model.

Ryc. la. Przed leczeniem; a - widok zewnatrzustny b-widok wewnatrzustny, $c-R T G O P G, d$-model orientacyjny.

reported pain on muscle and TMJ palpation. On examination acoustic symptoms clicking - were present. The Helkimo index was assessed as Ail and Di8, which indicates medium dysfunction.

The intraoral examination revealed missing teeth number 17, 15, 25, 27 and 46. Two failing posterior bridges were identified in regions 18-14 (supported by teeth $18,16,14$ ) and 2428 (supported by teeth 28, 26, 24) (Fig. 1b). There was a $2 \mathrm{~mm}$ discrepancy between the skeletal midline and the midline of the upper dental arch to the left. Partial lateral crossbite affected teeth 22, 23. Partial anterior crossbite is the result of previous prosthetic treatment that led to compensation of complete crossbite. On the right side of the arch a scissors bite was identified, partially compensated by the
$5 \mathrm{~mm}$ w stronę lewą, objawy akustyczne podczas ruchów- trzaski, ból podczas badania palpacyjnego mięśni i stawu skroniowo-żuchwowego. Określono wskaźnik na Ail oraz Di8, czyli średnią dysfunkcję.

$\mathrm{Na}$ podstawie badania wewnątrzustnego stwierdzono braki zębów 17, 15, 25, 27 i 46. W odcinkach bocznych zauważono nieszczelne mosty: 18-00-16-00-14 oraz most 24-00-00-0026-00-28 (ryc.1b). Widoczne było przesunięcie szkieletowej linii pośrodkowej od linii pośrodkowej górnego łuku zębowego o $5 \mathrm{~mm} \mathrm{w}$ stronę lewą. W obrębie zębów 22, 23 występował zgryz krzyżowy częściowy boczny. Po prawej stronie łuku zgryz przewieszony częściowo skompensowany z wykorzystaniem mostu 18-14 (ryc.1b). Test czynnościowy przesunięcia żuchwy w stronę prawą okazał się dodatni. 

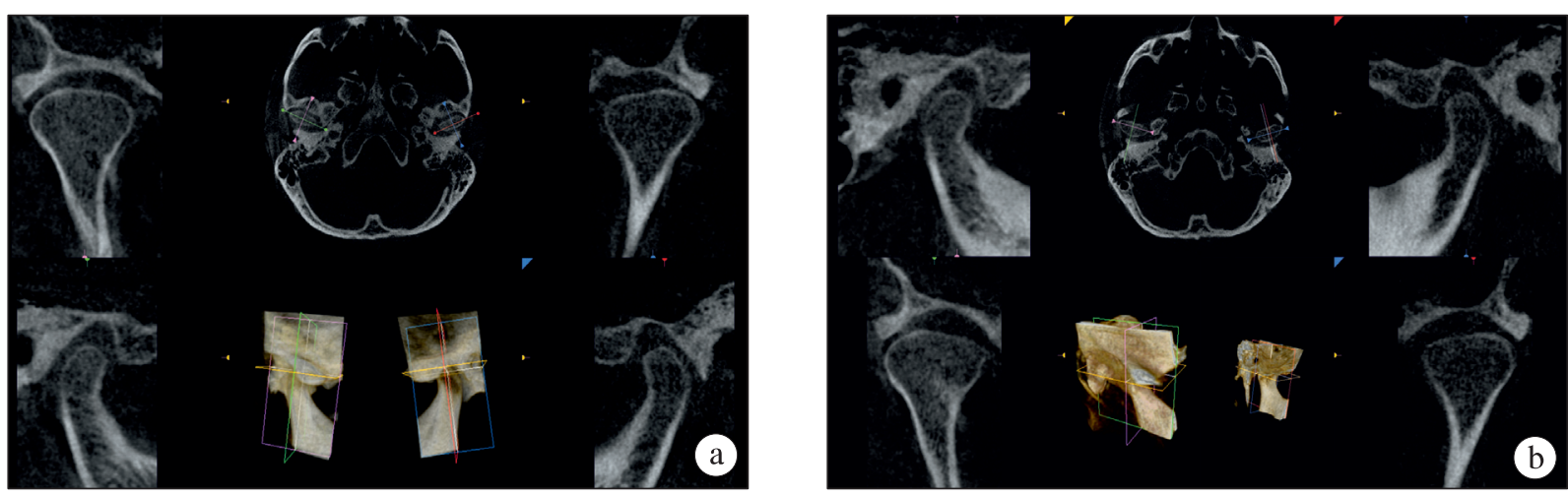

Fig. 2a. CBCT; $a$ - before deprogrammation, $b$-after deprogrammation.

Ryc. 2a. CBCT; $a$-przed deprogramacja, $b$ - po deprogramacji.

18-14 bridge (Fig. 1b). A functional test for mandibular shift to the right was positive.

Impressions were taken to produce plaster diagnostic models (Fig. 1d). A panoramic x-ray (CareStream 9300, Kodac) (Fig. 1c) and a CBCT scan of the temporomandibular joints were taken in habitual occlusion (CareStream 9300, Kodac) (Fig. 2a). The orthopantomogram revealed extensive periapical lesions around the roots 16, 14, 35. Previous root canal treatment of teeth $24,26,35$. The usage of transsectal section of cone beam computed tomography (CBCT) enables the diagnosis of TMJ. Although in CBCT articular disc is not visible, the examination shows the space of TMJ fissure, the location of heads of joints and the symmetry of condylar processes. A CBCT examination revealed the posterolateral position of the left condyle and the anteromedial position of the right condyle in the mandibular fossa (Fig. 2a). The patient was diagnosed with a lateral functional mandibular shift to the left side with simultaneous backward shift.

\section{Physiotherapy therapy}

The preparation to prosthethic treatment of patients with TMJ disorders should be precedeed by physiotherapy that releavies pain and alleviates tension of muscles. Due to tension in the cervical spine region, neck pain and pathological tooth
Wykonano wyciski w celu odlania modeli orientacyjnych z gipsu twardego (ryc.1d), zdjęcie pantomograficzne (CareStream 9300, Kodac) (ryc.1c) oraz tomografię stożkową w zwarciu nawykowym (CareStream 9300, Kodac) (ryc.2a). Na podstawie zdjęcia pantomograficznego, w okolicy okołowierzchołkowej zębów 16, 14, 35 stwierdzono rozległe zmiany. Zęby 24, 26, 35 leczone kanałowo. Zastosowanie tomografii stożkowej o zmiennym polu obrazowania w przekroju transektalnym umożliwia diagnostykę stawów skroniowo-żuchwowych. Choć w CBCT krążek stawowy jest niewidoczny, to za pomocą tego badania można ocenić przestrzeń szpary stawowej, położenie głów stawowych, symetrię wyrostków kłykciowych. W badaniu CBCT stwierdzono po stronie lewej tylno-boczne umiejscowienie głowy żuchwy w stawie, po stronie prawej przednio-przyśrodkowe umiejscowienie głowy żuchwy w stawie (ryc.2a). U pacjenta zdiagnozowano boczne lewostronne czynnościowe przemieszczenie żuchwy z dotylnym przesunięciem.

\section{Fizykoterapia i fizjoterapia}

Przygotowanie do leczenia protetycznego u pacjentów z ZCURNŻ powinna poprzedzać fizjoterapia, która pozwala ograniczyć dolegliwości bólowe oraz zmniejsza napięcia mięśni. Ze względu na zmiany napięciowe w odcinku 
wear, physical therapy was prescribed. Manual therapy was used to increase mobility in the areas of restricted musculoskeletal system activity, and to reduce pain. ${ }^{6}$ Additionally, rehabilitation with electrotherapy (TENS) was utilized. A low-frequency pulse current was used, which has a strong analgesic effect. ${ }^{7}$ Muscle massage of the masticatory organ was applied. This treatment included the application of pressure, rubbing, kneading and tapping. The individual muscles were massaged for three minutes, with the pressure gradually increasing. Massage stimulates the activity of the parasympathetic system. In response, the muscles relax and pain relief was is achieved. ${ }^{9}$

\section{Initial treatment}

In preparation for the prosthetic treatment, the sources of infection were eliminated and scaling was performed. Tooth 35 underwent endodontic retreatment and the new cast post and core was made of cobalt-chrome alloy (Schaftner). Then, the metal-ceramic bridge was removed from teeth 14-18. Teeth 14 and 16 were qualified for extraction due to extensive caries, periapical lesions and vertical root fracture in tooth 16. The treatment plan included an implantsupported bridge. Biomet3i (Biomed) implants were placed in $14,15,17$ positions and a lateral sinus floor augmentation lift? was performed (Fig. 3). Bridge 24-28 was removed and the

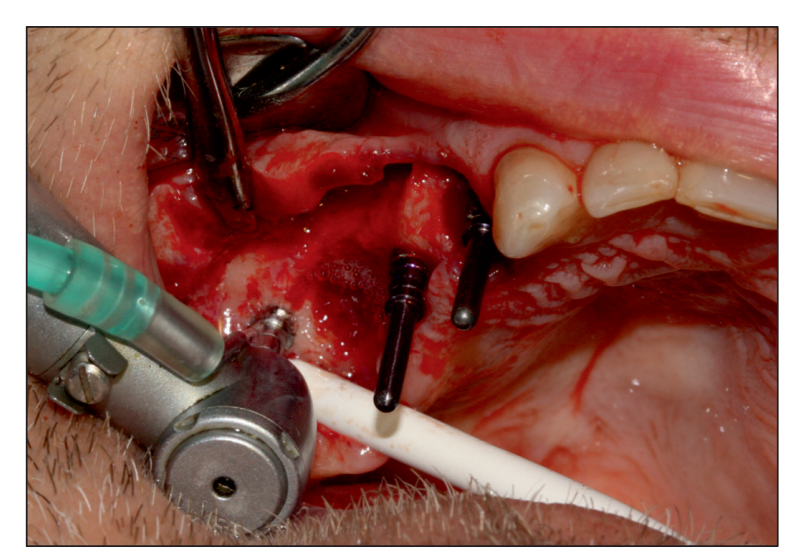

Fig. 3. Implantation.

Ryc. 3. Implantacja. szyjnym i bóle mięśni żucia zaordynowano fizjoterapię. Zastosowano terapię manualną $\mathrm{w}$ celu zwiększenia ruchomości w miejscach ograniczeń czynności układu mięśniowo-szkieletowego oraz zmniejszenia dolegliwości bólowych. ${ }^{6}$ Dodatkowo pacjent rehabilitowany był elektroterapią (TENS). Stosowano prąd impulsowy niskiej częstotliwości, który ma silne działanie przeciwbólowe. ${ }^{7}$ Zastosowano masaż mięśni narządu żucia. Wykorzystano ucisk, rozcieranie, ugniatanie oraz opukiwanie. Poszczególne mięśnie były masowane przez 3 minuty, stopniowo zwiększając ucisk. Masaż pobudza aktywność układu przywspółczulnego. W odpowiedzi dochodzi do relaksacji mięśni oraz uzyskania efektu przeciwbólowego. ${ }^{8}$

\section{Wstęne leczenie}

W ramach przygotowania do leczenia protetycznego przeprowadzono sanację jamy ustnej i wykonano higienizację (skaling). Przeprowadzono powtórne leczenie endodontyczne zęba 35 i wykonano powtórnie wkład koronowo-korzeniowego metalowy lany ze stopu chromo-kobaltowego (Schaftner). Następnie usunięto most metalowo-ceramiczny z zębów 14-18. Do ekstrakcji zakwalifikowano zęby 14 oraz 16 z powodu rozległej próchnicy, zmian okołowierzchołkowych oraz podłużnego pęknięcia korzenia w zębie 16. Podjęto decyzję o wykonaniu mostu opartego na implantach. Wprowadzono wszczepy Biomet3i (Biomed) w okolicy 14, 15, 17 i podniesiono dno zatoki szczękowej metodą otwartą (ryc.3). Zdjęto most 24-28, przeprowadzono kontrolę filarów. W lukę między zębami 44 i 45 wprowadzono wszczep Biomet3i. Wszystkie implantacje przeprowadzono $\mathrm{z}$ wykorzystaniem szablonu drukowanego zaprojektowanego w oprogramowaniu DDS Implants (Natrodent).

Zastosowano dwuetapową deprogramację, w celu prawidłowego ustalenia pozycji żuchwy w stosunku do szczęki w relacji centralnej. ${ }^{9,10}$ Jest to pozycja żuchwy wobec szczęki, 
abutment teeth were examined. A Biomet3i implant was placed between teeth 44 and 45 . All implant's procedures were performed using a printed template designed with DDS Implant software (Natrodent).

After a 6 month healing period following implant placement, a two-stage deprogramming procedure was performed to correctly align the mandible with the maxilla according to the central occlusion ma zostać centric relation., ${ }^{9,10}$ The centric relation is the position of the mandible in relation to the maxilla, independent of the occlusal contacts, in which the condyles are in an anterosuperior position relative to the posterior slopes of the articular processes (The Glossary of Prosthodontic Terms, GPT-9, 2017). ${ }^{12,13}$ In the first stage of the treatment, a NTI (nociceptive trigeminal inhibition) appliance was used (Fig. 4a), adapted to the maxillary central incisors with the Ortolab fast polymerizing resin (Snap), in order to achieve alignment of the midlines of both dental arches and disclusion of the posterior teeth (Fig. 4a). ${ }^{13}$ Vertical dimension of occlusion was raised by $1.5 \mathrm{~mm}$. The mandible of the patient was set in more central position, however the displacement to the left of midline of lower dental arch was still visible (Fig. 4b). The patient was recommended to wear the splint for 1.5 months, 3 times a day for 1.5 hours in a natural position. Prolonged use of the NTI is not recommended because it may cause complications: front teeth intrusion and back teeth extrusion. Then, short-term deprogamming was performed in the clinic using the Sliding Guide (Girrbach) method (deprogrammer thickness: $1.5 \mathrm{~mm}){ }^{14}$ Occlusal registration was made in this position using silicone recording material. The central positioning of the mandibular heads in fossas w dołach was confirmed with CBCT scans of the TMJs (Fig. 2b). Impressions were taken to produce working models, mounted subsequently in an articulator. A technician prepared the waxup (Fig. 5a) and silicone index. Oral mock-ups were made with Luxatemp (DMG) (Fig. 5b). niezależna od kontaktów zębów, w której kłykcie znajdują się w położeniu przednio-górnym względem tylnych stoków wyrostków stawowych (The Glossary of Prosthodontic Terms, GPT-9, 2017). ${ }^{11,12} \mathrm{~W}$ pierwszym etapie leczenia wykonano szynę NTI (nociceptive trigeminal inhibition) (ryc.4a). Szynę osadzono za pomocą uszczelniającego materiału szybkopolimeryzującego (Snap, Ortolab) na górnych zębach siecznych przyśrodkowych, tak by uzyskać zgodność linii pośrodkowych obu łuków zębowych oraz dyskluzję w obrębie zębów bocznych (ryc.4a). ${ }^{13}$ Podniesiono zwarcie o 1,5 mm. Pacjent ustawił żuchwę w pozycji bardziej centralnej, choć nadal obserwowano przesunięcie linii dolnego łuku zębowego w lewo (ryc.4b). Zlecono stosowanie szyny przez 1,5 miesiąca, codziennie, 3 razy $\mathrm{w}$ ciągu dnia po 1,5 godziny $\mathrm{w}$ pozycji naturalnej. Szyny NTI nie należy stosować długoczasowo, gdyż może dojść do powikłań w postaci intruzji zębów przednich oraz ekstruzji zębów bocznych. Po tym okresie, w gabinecie przeprowadzono krótkoczasową deprogamację metodą Sliding Guide (Girrbach) o grubości 1,5 mm. ${ }^{14}$ W tej pozycji wykonano rejestrat zwarciowy za pomocą masy silikonowej. Uzyskano centralne spozycjonowanie głów stawowych w dołach, co zostało potwierdzone na CBCT stawów (ryc. 2b). Pobrano wyciski w celu wykonania modeli roboczych, które zamontowano w artykulatorze. Technik przygotował wax-up (ryc.5a) i indeks silikonowy. Wykonano mock-up w jamie ustnej z Luxatemp (DMG) (ryc.5b). Oceniono estetykę, fonetykę oraz funkcję pacjenta w tymczasowych uzupełnieniach. ${ }^{15,16}$ Pacjent użytkował tymczasowe uzupełnienia przez 6 miesięcy. W tym okresie implanty uległy osteoinegracji.

\section{Dlugoczasowa odbudowa}

Następnie przeprowadzono nieznaczne szlifowanie zębów 13 do 23 pod licówki oraz niewielką korektę kształtu fillarów 24, 26 i 28 do mostu (ryc.6). Pobrano wyciski masami Aqasil (Densplay). Przeniesiono zaadoptowane 

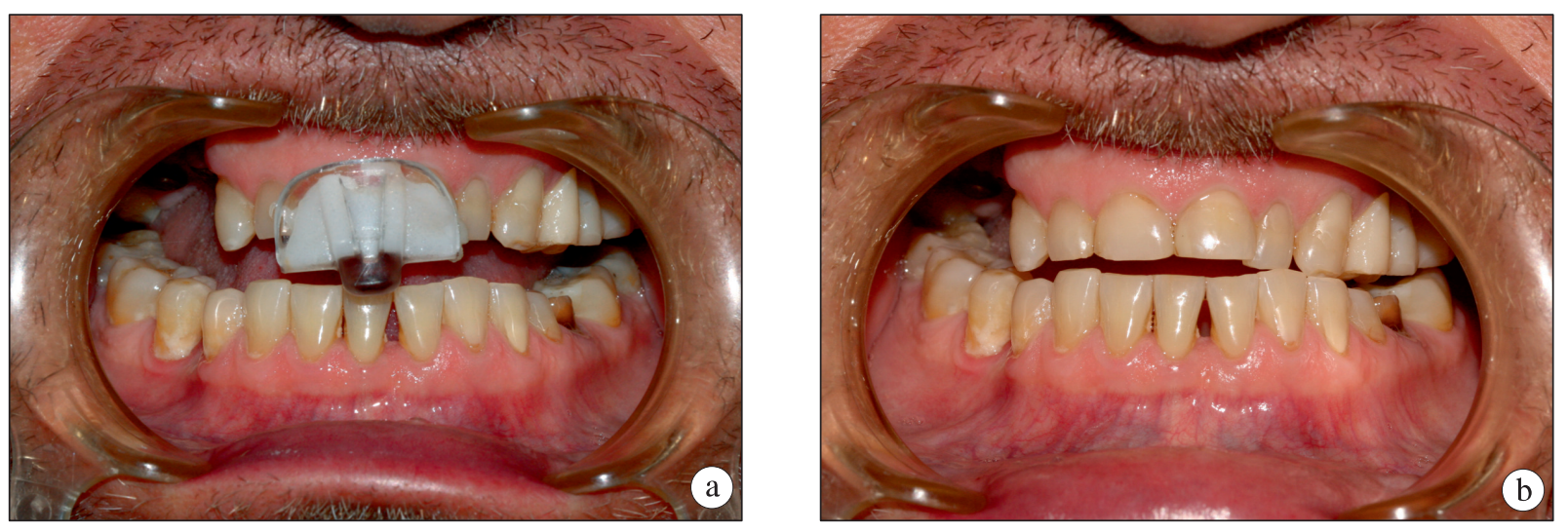

Fig. 4. Intraoral view; a - NTI splint (nociceptive trigeminal inhibition), $b$ - view after deprogrammation. Ryc. 4. Widok wewnątrzustny; $a$-szyna NTI, $b$-widok po deprogramacji.
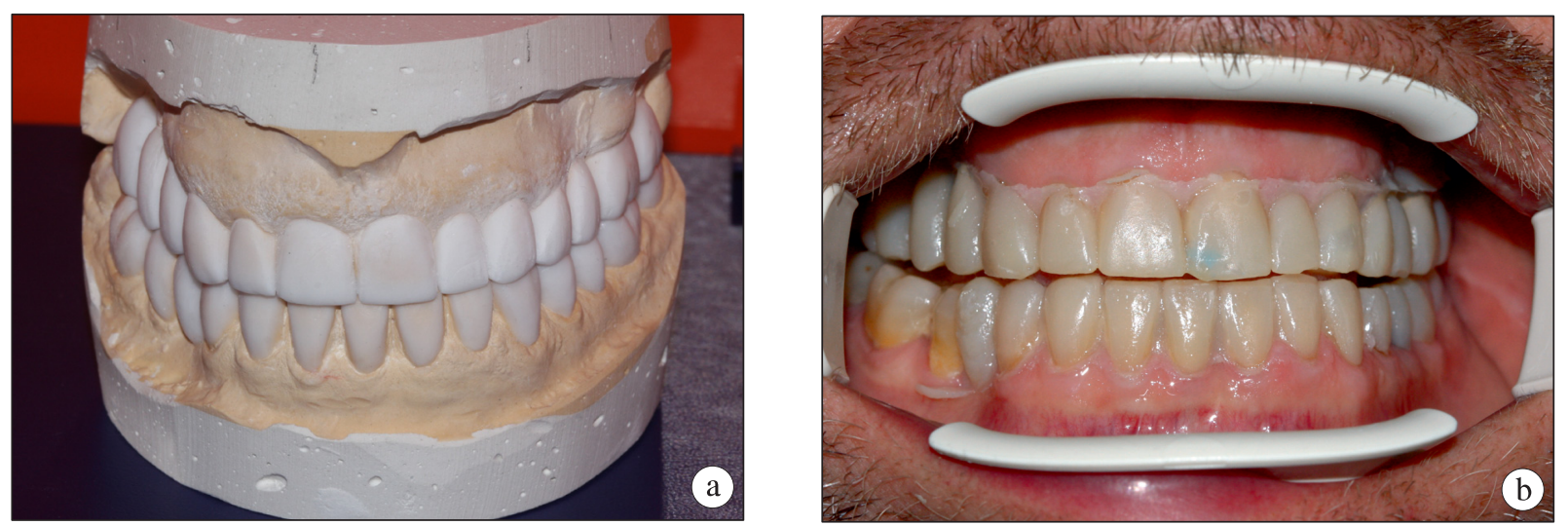

Fig. 5.a-cast models: diagnostic wax-up, b-mock up - intraoral view.

Ryc. 5. a-modele: wax-up diagnostyczny, $b$ - mock-up - widok wewnatrzustny.

Aesthetics, phonetics and function of the temporary restoration were assessed. ${ }^{15,16}$ The patient was using the temporary restoration for three months. During this time implants becomed underwent osseointegration.

\section{Final prosthetic appliance}

Then, teeth 13 to 23 were slightly prepared for veneers, while abutments 24, 26 and 28 were moderately corrected (Fig. 6). Aqasil (Densplay) impressions were taken. and final prosthetic appliances did not damage. Teeth 24-26-28 were covered with a bridge on a metal framework, veneered with Sakura ceramics (Densply) (Fig.7). The bridge was cemented with Fuji Plus GC cement. Veneers for teeth 13-23 were made zwarcie konstrukcyjne do artykulatora za pomocą silikonowych rejestratów zwarcia. W tym układzie wykonano most 24-00-00-26-00-28 na podbudowie metalowej, licowany porcelaną Sakura (Densply) (ryc.7). Most osadzono na cement Fuji Plus GC. W obrębie zębów 13-23 przygotowano licówki z e-max Press (Ivoclar). Na łącznikach tytanowych wszczepów 14, 15, 17 wykonano most na podbudowie z tlenku cyrkonu (Ceramill Zolid, Girrbach). W żuchwie osadzono nakłady emax Press (Ivoclar) na zębach 36 i 46 oraz licówki okluzyjne emax Press (Ivoclar) na zębach 33, 34 i 44, 45. Prace osadzono na cement dualny firmy CementIt (Pentron), licówki na cement Mojo Clear (Pentron) (ryc.7 i 8). 


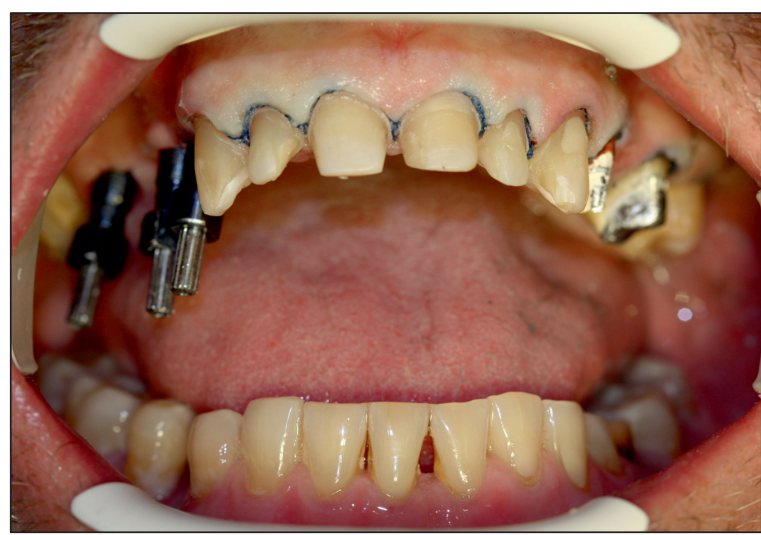

Fig. 6. Post implantation intraoral view, teeth preparation.

Ryc. 6. Stan po implantacji - widok wewnatrzustny, opracowanie zębów.

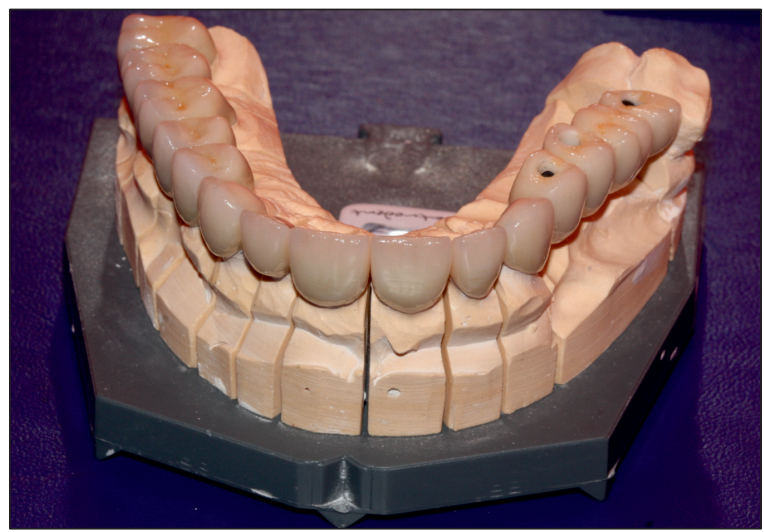

Fig. 7. Final prosthetic appliance.

Ryc. 7. Ostateczna praca protetyczna.

with e-max Press (Ivoclar). A zirconia-based bridge (Ceramill Zolid, Girrbach) was made for the titanium implant abutments $14,15,17$. In the mandible emax Press (Ivoclar) onlays were cemented on teeth 36 and 46 and emax Press occlusal veneers (Ivoclar) on teeth 33, 34, 44, 45. The onlays were cemented with CementIt (Pentron) dual cement, and the veneers with Mojo Clear cement (Pentron) (Fig. 7, 8).

\section{Discussion and results}

It is said that malocclusions rarely cause tempomandibular disorders with acoustic phenomena. ${ }^{17}$ However, in the case described
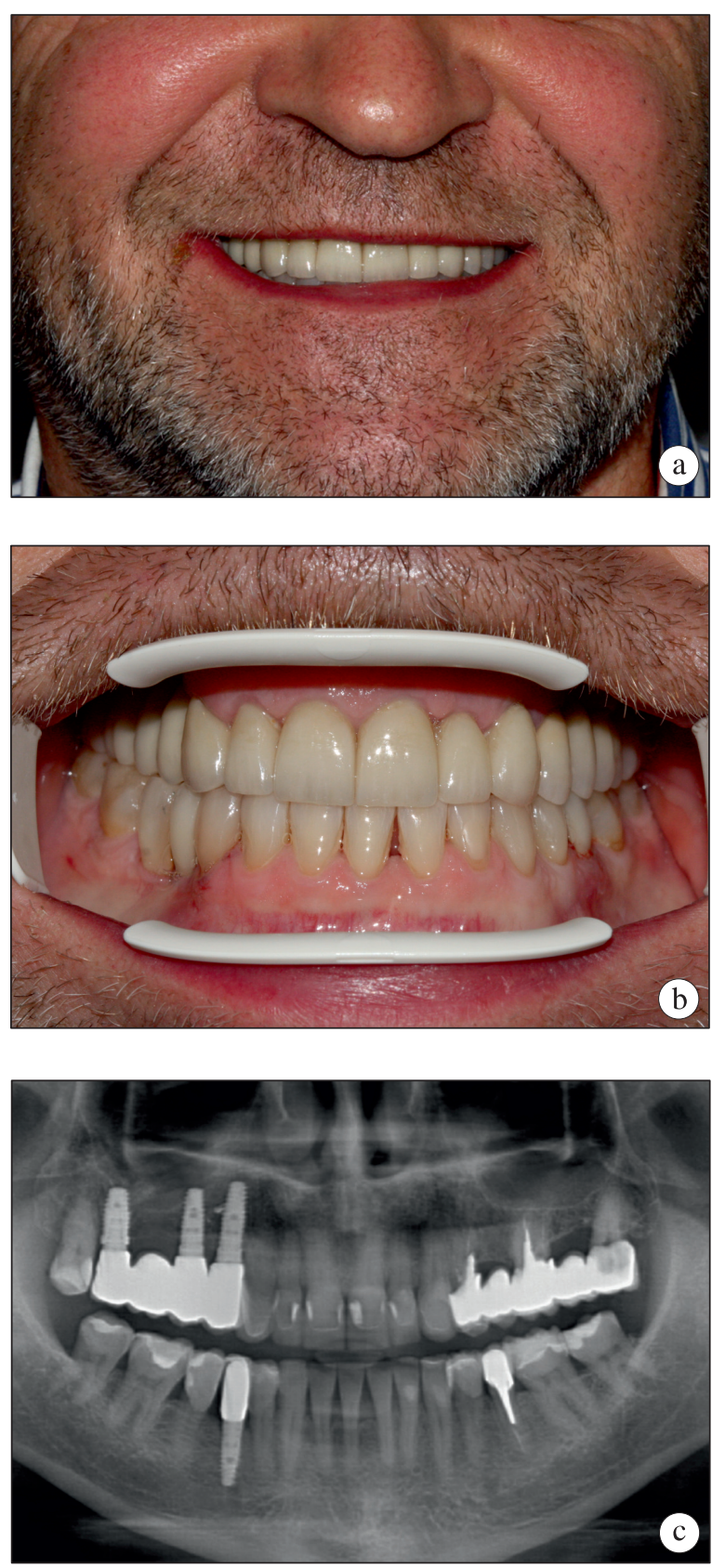

Fig. 8. After treatment; a-extraoral view, $b$-intraoral view, $c-R T G O P G$.

Ryc. 8. Po leczeniu; $a$-widok zewnatrzustny, $b-$ widok wewnatrzustny, c-RTG OPG.

\section{Podsumowanie i dyskusja}

Uważa się, że wpływ wad zgryzu na powstanie ZCZNZ z objawami akustycznymi w stawach jest niewielki, ${ }^{17}$ to jednak w opisanym 
above the patient manifested lateral functional mandibular dislocation complicated with iatrogrenic errors of previous prosthetic treatment. That lead to TMJ disorders.

The treatment described above was carried out in 2012-2014. An interdisciplinary procedure encompassed modern diagnostics, appropriately selected physical therapy methods and comprehensive implantoprosthetic treatment. Functional and aesthetic prosthetic restorations were made. The treatment improved the patient's facial profile. Unfortunately, only partial compensation of lateral functional mandibular dislocation was observed. ${ }^{10}$

The patient reported that myalgia had resolved. The range of mandible movements improved, small mandible deviation to the left side remained. Reduction of muscle tension was noted. In addition the frequency of acoustic phenomena diminished. The pain that had been present on palpation of the muscles and the TMJ disappeared. After rehabilitation and prosthetic treatment the Helkimo index was Ai0 and Di2.

During the nine-year follow-up, no pathological tooth wear or gingival recession were observed. Nor was any bone loss observed. (Fig.8c).The effects were long-lasting and final prosthetic appliances did not damage.

By deprogramming and establishing the centric relation central occlusion, stable occlusion can be achieved together with compensating for the lateral functional mandibular shift, which has been confirmed by other authors. ${ }^{18,19}$ przypadku stwierdzono $\mathrm{u}$ pacjenta boczne czynnościowe przesunięcie żuchwy, powikłane jatrogennymi błędami leczenia protetycznego, co doprowadziło do zmian czynnościowych układu ruchowego narządu żucia.

Opisane powyżej leczenie zostało przeprowadzone w latach 2012-2014. Zastosowano postępowanie interdyscyplinarne: nowoczesną diagnostykę, właściwie dobrane metody fizjoterapeutyczne oraz kompleksowe leczenie implantoprotetyczne. Wykonano funkcjonalne i estetyczne uzupełnienia protetyczne. Leczenie doprowadziło do poprawy rysów twarzy. Jednak uzyskano tylko częściową kompensację bocznego czynnościowego przemieszczenia żuchwy. Pacjent relacjonował ustąpienie dolegliwości bólowych mięśni. Zakres ruchów żuchwy się poprawił, pozostało niewielkie odchylenie żuchwy w stronę lewą, zaobserwowano redukcję napięć mięśniowych, częstość objawów akustycznych w stawie uległa zmniejszeniu, ustąpił ból podczas badania palpacyjnego mięśni i stawu skroniowo-żuchwowego. Po rehabilitacji i leczeniu protetycznym wskaźnik Helkimo określono na Ai0 oraz Di2.

Podczas dziewięcioletniej obserwacji nie odnotowano patologicznego starcia zębów oraz recesji dziąseł. Nie doszło także do zaników kostnych (ryc.8c). Efekty leczenia były trwałe, a prace długoczasie nie uległy uszkodzeniu. Dzięki deprogramacji i ustaleniu prawidłowej relacji centralnej w stawach sż można uzyskać stabilne zwarcie i eliminację zaburzeń czynnościowych narządu żucia, co potwierdzają inni autorzy. ${ }^{18,19}$ 


\section{References / Piśmiennictwo}

1. Gauer RL, Semidey MJ: Diagnosis and treatment of temporomandibular disorders. Am Fam Physician 2015; 91: 378-386.

2. Zhi-Hui Mai QC, et al.: Treatment of a mandibular functional shift in an adolescent boy with temporomandibular disorder and crossbites. Am J Orthod Dentofac 2015; 148 : 660-673.

3. Sharma DS, Srivastava S, Tandon $S$ : Preventive orthodontic approach for functional mandibular shift in early mixed dentition: A case report. J Oral Biol Craniofac Res 2019; 9: 209-214.

4. Kennedy B, Osepchook M: Unilateral posterior crossbite with mandibular shift: A review. JCDA 2005; 8: 569-573.

5. Dawson PE: Temporomandibular joint pain-dysfunction problems can be solved. J Prosthet Dent 1973; 29: 100-112.

6. Okeson JP, et al.: Comparison of psychologic and physiologic functioning between patients with masticatory muscle pain and matched controls. J Orofac Pain 1993; 7: 15-22.

7. Kasat $V$, et al.: Transcutaneous electric nerve stimulation (TENS) in dentistry- A review. J Clin Exp Dent 2014; 6: 562-568.

8. Jayne D: A deprogrammer for occlusal analysis and simplified accurate case mounting. J Cosmet Dent 2006; 21: 96-102.

9. Wiens JP, et al.: Defining centric relation. $\mathrm{J}$ Prosthet Dent 2018; 120: 114-122.

10. Rinchuse DJ, Kandasamy S: Centric relation: A historical and contemporary orthodontic perspective. J Am Dent Assoc 2006; 137: 494-501.

11. The glossary of prosthodontic terms. 9th edn. J Prosthet Dent 2017: 117.

12. Nitecka-Buchta A, et al.: Functional
Assessment of the stomatognathic system, after the treatment of edentulous patients with different methods of establishing the centric relation. Pain Res Manag 2018; 4: 157-173.

13. Stapelmann H, Türp JC: The NTI-tss device for the therapy of bruxism, temporomandibular disorders, and headache - Where do we stand? A qualitative systematic review of the literature. BMC Oral Health 2008; 8: 1-23.

14. Rickne C. Woelfel's Dental Anatomy. USA: Lippincott Williams \& Wilkins; ed., 2011.

15. De Vos W, Casselman J, Swennen GRJ: Conebeam computerized tomography (CBCT) imaging of the oral and maxillofacial region: A systematic review of the literature. Int J Oral Maxillofac Surg 2009; 6: 609-625.

16. Chicarelli $M$, et al.: Temporal bone pneumatization in patients with dentofacial deformities: cone beam computed tomography study. Int J Oral Maxillofac Surg 2019; 48: 1564-1569.

17. Manfredini D, Perinetti G, Guarda-Nardini $L$ : Dental malocclusion is not related to temporomandibular joint clicking: a logistic regression analysis in a patient population. Angle Orthod 2014; 84: 310-315.

18. Biagioni $A$, et al.: The role of occlusion on full mouth rehabilitations with adhesive partial crowns. A systematic review. J Osseointegr 2020; 12: 161-166.

19. Darraj A, Mattoo KA: Full mouth rehabilitation involving occlusal plane correction-case report. JMSCR 2017; 9: 28204-28208.

Zaakceptowano do druku: 30.11.2021 r.

Adres autorów: 92-213 Łódź, ul Pomorska 251.

(C) Zarząd Główny PTS 2021. 